\title{
Discharge of hydronium ions on metal cathodes in the presence of pyridine
}

\author{
(C) Alexander V. Kolesnikov, ${ }^{*+}$ and E.I. Ageenko \\ Chelyabinsk State University. Brothers Kashirinykh St., 129. Chelyabinsk, 454001. Russia. \\ Phone:+7 (357) 794-25-12.E-mail:avkzinc-gu@yandex.ru
}

\begin{abstract}
*Supervising author; ${ }^{+}$Corresponding author
Keywords: pyridine, sulfuric acid, electrolyte, discharge, copper, aluminum, zinc, lead cathode, current density, hydronium ion.
\end{abstract}

\begin{abstract}
In this work, studies have been carried out on the electrochemical reduction of hydrogen (hydronium ion) from acidic aqueous solutions in the presence of an organic substance - pyridine. Electrolysis was carried out in an electrolyte with a sulfuric acid content $(0.18 ; 0.36 \mathrm{M})$ with a pyridine additions of $8.4 \cdot 10^{-3} \mathrm{M}$. Potentiostatic studies were carried out on a Potentiostat P-30Jcom Elins potentiostat using a three-electrode cell. Working electrodes (cathodes) were made of M1 copper with an area (S) of $0.09 \mathrm{~cm}^{2}$; aluminum (AD1) S $-0.125 \mathrm{~cm}^{2}$, zinc (Ts0A) S $0.35 \mathrm{~cm}^{2}$, lead $(\mathrm{Cl}) \mathrm{S}-0.20 \mathrm{~cm}^{2}$, auxiliary (anode) - from a platinum plate with an area of $0.20 \mathrm{~cm}^{2}$, reference electrode - silver chloride $(\mathrm{AgCl} / \mathrm{Ag})$. In potentiometric measurements, the results are presented according to the average data obtained for $30 \mathrm{~s}$ of electrolysis in the potential range $(-950 \div-1100 \mathrm{mV}$ for $\mathrm{AgCl} / \mathrm{Ag}$ ), and in studies in the galvanostatic mode at current densities from 0 to $110 \mathrm{mV} / \mathrm{cm}^{2}$, the results are presented as average data, obtained in the initial $5 \mathrm{~s}$ of the process.

The paper presents comparative data on the electrokinetic parameters studied under the same conditions of hydrogen discharge reactions at different cathodes in electrolytes with a sulfuric acid content of $0.36 \mathrm{M}$. It is shown that the highest discharge current density of the hydronium ion $\left(\mathrm{H}_{3} \mathrm{O}^{+}\right)$is achieved at the copper electrode, and the lowest at the lead electrode. With the addition of $8.4 \cdot 10^{-3} \mathrm{M}$ pyridine to the electrolyte, the reduction of hydrogen cations is somewhat reduced on the electrodes used, except for lead. The transfer coefficients of the hydrogen discharge at all electrodes are low, and with the addition of pyridine they decrease even more. The low transfer coefficients indicate that the process of the hydronium ion discharge proceeds in a non-activation mode. The lowest exchange current is recorded at the copper and lead electrode. At the zinc electrode, the exchange of current is one to two orders of magnitude higher than at the other electrodes, so it can be noted that at this electrode the system under consideration is closer to the equilibrium of state.

The order of the reaction of the course of electrolysis by the hydronium cation on the copper, aluminum and zinc electrodes is close to unity. The addition of pyridine leads to a slight decrease in the order of the reaction. This is due to the fact that pyridine molecules in acidic solutions exist in the form of pyridinium ion, which is reduced at the cathode. In this case, a significant amount of hydrogen is absorbed, which should explain the decrease in the order of the reaction with respect to the hydronium ion in the presence of pyridine additives. The obtained low values of the transfer coefficients indicate that, during the discharge of hydronium ions, the process is limited to a greater extent by the concentration polarization. The diffusion nature of the reduction of hydronium ions in electrolytes with a sulfuric acid concentration of 0.18 and $0.36 \mathrm{M}$ is also evidenced by data taken in a dynamic mode.
\end{abstract}

\section{References}

[1] D.A. Ponomarev, M.D. Plotnikova, A.B. Shein, A.E. Rubtsov. Investigation of the protective action of thiazole and thiadiazole derivatives on mild steel in hydrochloric acid solution. Vestn. Perm. un-that. Ser. Chemistry. 2018. Iss.3(31). P.349-359. DOI: 10.17072/2223-1838-2018-3-349-359

[2] A.B. Shein, M.D. Plotnikova, A.E. Rubtsov. Protective properties of a number of thiadiazole derivatives in sulfuric acid solutions. News of Universities. Chemistry and Chem. Technology. 2019. Vol.62. Iss.7. P.123-129. (DOI: 10.6060/ivkkt.20196207.5968

[3] V.I. Vigdorovich, L.Ye. Tsygankova, D.V. Balybin, V.I. Kichigin, D.V. Krylsky. Kinetics and nature of the delayed stage of the reaction of cathodic hydrogen evolution on iron in aqueous and water-ethylene glycol solutions of $\mathrm{HCl}$ in the presence of $o$-fluorophenylbiguanidine. Electrochemistry. 2013. Vol.49. No.11. P.1166. DOI: 10.7868/S0424857013110133 
[4] M.A. Mokrushin, A.B. Shein, A.E. Rubtsov. Search for potential corrosion inhibitors among sulfurcontaining organic compounds. Vestn. Perm. un-that. Ser. Chemistry. 2017. Vol.27. Iss.3. P.271-278. DOI: $10.17072 / 2223-1838-2017-3-271-278$

[5] K.V. Rybalka, L.A. Beketaeva, A.D. Davydov. Determination of the density of the corrosive current from the flow rate of the cathode depolarizer. Electrochemistry. 2016. Vol.52. No.3. P.310-314. DOI: $10.7868 / \mathrm{S} 0424857016030099$

[6] K.V. Rybalka, L.A. Beketaeva, A.D. Davydov. Determination of the density of the corrosion current on smooth and powdered nickel by the flow rate of the cathode depolarizer. Electrochemistry. 2016. Vol.52. No.10. P.1035-1038. DOI: 10.7868/S042485701610110

[7] K.V. Fishing, L.A. Beketaeva, A.D. Davydov. Evaluation of the corrosion current based on the analysis of polarization curves. Electrochemical kinetics mode. Electrochemistry. 2014. Vol.50. No.2. P.122-127. DOI: $10.7868 / \mathrm{S} 042485701402003$

[8] V.V. Kuznetsov, Yu.D. Hamburg, N.V. Zhalnerov, V.V. Zhulikov, R.S. Batalov. Reactive hydrogen evolution on Co-Ni (W) and Ni-Re alloys in alkaline solutions. Electrochemistry. 2016. Vol.52. No.9. P.1011-1021. DOI: 10.7868/S0424857016090061

[9] R. Solmaz, G. Kardas, M. Gulha, B. Yazici, M. Erbil. Investigation of the adsorption and inhibitory effect of 2-mercapto-thiazoline on the corrosion of mild steel in hydrochloric acid media. Electrochim. Acta. 2008. Vol.53. P.5941-5952. DOI: 10.1016/j.electacta.2008.03.055

[10] R. Solmaz, G. Kardas, B. Yazici, M. Erbil. Adsorption and anticorrosive properties of 2-amino-5mercapto-1,3,4-thiadiazole on mild steel in hydrochloric acid media. Colloid. Surf. A: Physicochem. Eng. Asp. 2008. Vol.312. P.7-17. DOI: 10.1016/j.colsurfa.2007.06.035

[11] A.V. Kolesnikov, and E.I. Ageenko. The effect of pyridine on the electrochemical parameters of the hydroxonium discharge at the copper cathode. Butlerov Communications. 2019. Vol.60. No.12. P.6269. DOI: $10.37952 /$ ROI-jbc-01/19-60-12-62

[12] P.A. Kozlov, A.V. Kolesnikov. Features of zinc electrolysis in the presence of pyridine. Non-ferrous metals. 2020. No.5. P.72-76. (russian)

[13] A.V. Kolesnikov, P.A. Kozlov. Zinc electrolysis in sulfate solutions. Non-ferrous metals. 2018. No.8. P.45-49. (russian)

[14] L.A. Kazanbaev, P.A. Kozlov, V.L. Kubasov, A.V. Kolesnikov. Zinc hydrometallurgy (solution purification and electrolysis). Moscow: Publishing house "Ore and Metals". 2006. 176p. (russian)

[15] L.V. Sapronova, N.V. Sotskaya, O.V. Dolgikh. Kinetics of nickel electrodeposition from complex electrolytes containing amino acids. Condensed media and interphase boundaries. 2013. Vol.15. No.4. P.446-452. (russian)

[16] L.I. Kristalik. Electrode reactions. The mechanism of an elementary act. Moscow: Science. 1982. 224p. (russian) 